\title{
French from Here, is it French? The Construction of Normativity Judgements in Peripheral European Francophone Communities ${ }^{1}$
}

Michel Francard ${ }^{a}$

${ }^{1}$ This article is the translation of the following work: FRANCARD, Michel. 2018. « Le français d'ici est-il du français? Jugements de normativité dans les communautés francophones périphériques européennes ». Dans Laurence ARRIGHI \& Karine GAUVIN (dir.), Regards croisés sur les français d'ici. Québec: Presses de l'Université Laval, p. 251-268. We thank very sincerely Michel Francard for permitting these translations and for having condensed his recent article about grammatical Belgicism, this part of the linguistic field not being explored in the first yet. We also thank very profoundly the editors and directors of both the publications where these articles were published at first, for permitting these translations.

\begin{abstract}
This article deals with the diatopic variation of French in its relation to normative discourse, more specifically French as practised in Belgium, exemplified here by the fields of lexicon and syntax. It describes the purist discourse of the last century which is evolving towards a modification of the normative hierarchy, an emancipation from linguistic hegemony, both in the scientific world and in the representations of the speakers. It also leads to a valuable questioning of the identity of the actors responsible for the construction of normative judgements.
\end{abstract}

Keywords: Belgian French. Endogenous norm. Normative discourse. Syntax. Glottopolitical actors.

\footnotetext{
a Universidade Católica de Louvain, Faculdade de Filosofia, Artes e Letras.Louvain, Bélgica.

E-mail: michel.francard@uclouvain.be
}

\section{How to cite:}

Francard, M. French from Here, is it French? The Construction of Normativity Judgements in Peripheral European Francophone Communities. Gragoatá, Niterói, v.26, n.54, p. 26-50, 2021. 
${ }^{2} \mathrm{Cf}$. in particular the Manifesto of the Association québécoise des professeurs de français: « Le français standard d'ici est la variété de français socialement valorisée que la majorité des Québécois francophones tend à utiliser dans les situations de communication formelle» (1977, p. 11). ('The standard French from here is the variety of socially valued French that the majority of French-speaking Quebecers tend to use in formal communication situations.').

${ }^{3}$ See Francard (1994 and 2005) for comparisons between these communities.

\section{Introduction}

The invitation to present this inaugural lecture of the fifth edition of the Les français d'ici conference particularly touched me, because of the venue chosen for this meeting. It so happens that the Universite de Moncton is the first North American university to which I was invited for a series of courses and seminars on the European Francophonie.

This first visit, which was followed by several others and by fairly regular contact with the reality of the Acadian Francophonie, dates back to 1985, at a time when my research was already focusing on the geographical variation of French, not only from a descriptive point of view, but also from the point of view of how speakers perceived it in their representations. This research was rooted in a field where the normative (sometimes even purist) tradition weighed heavily. The "hunt for belgicisms" was still in full swing, clearly out of step with what I then knew of Quebec and its assumed claim to a "standard French from here". 2

Even if I understood, later on, that the political, social and cultural reality in Quebec was more complex than I had perceived it from Europe, the linguistic situation of this "distinct society" was hardly comparable to that of the French-speaking communities in Western Europe, still largely dominated by the "French" (from France) model. Nor was it comparable with the Acadian linguistic community that I discovered, thanks to colleagues at the Université de Moncton - in particular Louise Péronnet and Annette Boudreau - who were much more familiar to me, due in part to the linguistic insecurity that was evident there.

While the representations shared between Acadia and Wallonia are similar in nature, the scope of their manifestations differs, however. My research in Acadia has given me access to a sociolinguistic reality that is much clearer than in my own country, much more explicit in the issues at stake, and much more challenging in terms of the balance of power between the linguistic communities involved and the ideologies that underlie these relationships ${ }^{3}$.

The title of this presentation is, of course, a nod to the generic title of this series of colloquia devoted to the varieties of French in Canada. I will deal with the geographical (diatopic) 
${ }^{4}$ Stigmatisation of social and stylistic variation takes other paths and manifests itself in other forms than those which weigh on geographical variation. For social and stylistic variation in the French language, we will refer (among others) to the work of Bourdieu and Gadet.

\footnotetext{
${ }^{5}$ The omnibus of language, or the regulator of vicious idioms, disfigured or misused words, improper terms, all the faults that escape ignorance or inattention
}

variation of French in its relationship with normative discourse. I will not attempt to cover the varieties of French in North America, but I will limit myself to European varieties, focusing on the French spoken in Belgium, with a few escapades to French-speaking Switzerland and the so-called "regions of France". In addition, most of the illustrations will be borrowed from the lexicon field, one of the fields - along with pronunciation - which is most clearly perceived as a vector of geographical variation.

This presentation describes the evolution of normative judgements about geographical variation in peripheral European francophone communities. Firstly, by describing the purist tradition that prevailed until the end of the last century; secondly, by evoking some significant developments, both epistemological and methodological, that have contributed to modifying the normative hierarchy, both in the disciplinary field and in the representations of speakers. Finally, we will question the identity of the actors responsible for the construction of normative judgements.

\section{The stigmatisation of geographical variation}

Geographical variation has not been well received in the French-speaking world until recently. Like other types of variation, which are also widely decried, such as social or stylistic variation ${ }^{4}$, this geographical variation was very early on perceived as particularly harmful to the "correct" use of French.

\section{An age-old tradition}

This tradition developed in Europe as early as the sixteenth century, with the "remarqueurs" (AYRES-BENNETT, 1994), and was subsequently amplified both in Europe and in Canada from the nineteenth century onwards. One of the many faces it has adopted includes these cacographies that track barbarisms, solecisms, neologisms and other shameful -isms.

One illustration - among thousands of others in Europe is the collection entitled L'omnibus du langage, ou le régulateur des locutions vicieuses, des mots défigurés ou détournés de leur sens, des termes impropres, de toutes les fautes qui échappent à l'ignorance ou à l'inattention ${ }^{5}$ (BARTHÉLEMY, 1839). It is significant to observe 
that the said "regulator" reproduces a quotation from Boileau (1636-1711) at the top of the page:

This contagion infecting the provinces,

From the clerk and the bourgeois to the princes.

(Poetic art, 1674)

While the main types of error found in this Omnibus (and those that follow) are not mainly related to geographical variation, the sources of the "conspiracy against the purity of the French language" (BARTHÉLEMY, 1839, p. iv) are immediately identified as "provincial", in a relationship between "province" and "capital" that will later be found under the name "centre-periphery".

We are in a Jacobin conception of the state, centralised and united by its own language. It is a language that also expresses all the dominant moral values of the time, which is what the author of the Omnibus claims; he quotes, at the end of the introduction, this word from the king to Mr. Dureau de la Malle: "Do carefully preserve the French language; for words preserve ideas" (BARTHÉLEMY, 1839, p. vi). The same author is also pleased to have given his collection "a moral side" (BARTHÉLEMY, 1839, p. vi).

This discrediting of any form of "local French" (where "here" would not be at the centre of France) is understandable in the context of the emergence of a "national French" in France in the nineteenth century. It is much less so in French-speaking areas that are independent of France (such as Acadia or Quebec) or that have become independent of it, such as Belgium.

Precisely in Belgium, the purist tradition stigmatising geographical particularisms began with a certain Poyart who, in 1806, published a collection denouncing "flandricisms, Walloonisms and improper expressions in the French language", in other words the "faults frequently committed by Belgians in speaking or writing the French language".

Antoine Poyart is a French citizen, whose book appears at a time when Belgium, then attached to France, does not yet exist as an independent state. Poyart is therefore concerned that Belgians, as French citizens, should share the language of their French fellow citizens. Once Belgium became independent, the tradition inaugurated by Poyart would be continued 
and amplified, even though what justified it - the Belgians' belonging to the French nation - had ceased to be relevant.

This purist tradition will continue throughout the French-speaking world until the 1960s, and sometimes even beyond. In Belgium, it culminated in the Chasses aux belgicismes (HANSE ET AL., 1971 and 1974), which were a huge success in bookshops (tens of thousands of copies sold) and were widely distributed in schools.

The same purist tradition was to fuel linguistic insecurity, which has been abundantly documented for peripheral francophone communities (FRANCARD et al., 1993-1994). Its main epilinguistic manifestations for French-speaking Belgium can be summarised in four points:

1. subjection in relation to the "French model"

2. self-deprecation of language practice

3. use of compensation strategies

4. pessimism of 'clerics' about the future of French (FRANCARD et al., 1993).

Many subsequent studies - some of them conducted in Acadia - have largely confirmed our findings for Belgium and attest to a lack of linguistic legitimacy shared by many French-speakers, those from peripheral communities who are inferior to the Paris norm - a norm which, as has been shown, is largely mythified.

The primacy of the exogenous norm

An essential feature of this stigmatisation of geographical variation is therefore the denial of any legitimacy to what is "local French", compared to "French from here", "French from Paris", "correct French", etc. In other words, the "peripheral" (as opposed to the "central") French-speaking communities have to regulate their uses according to an exogenous norm, the only one in force within the "official" language market.

Such a clear-cut position does not long stand up to analysis, nor does it stand up to confrontation with practices. This explains the "compensatory strategies" mentioned above, which play on the distinction between the official market, 
${ }^{6}$ It turns out that drève comes from the Middle Dutch dreve, which itself is derived from the verb drijven. 'to drive'. dominated by exogenous norms, and restricted (regional) markets where endogenous norms can find some legitimacy.

In Belgium, even the authors of the Chasses aux belgicismes had to make some concessions in relation to purist intransigence. Hence the recognition of "belgicisms de bon aloi" (DOPPAGNE, 1979) - to which will correspond "helvetisms de bon aloi", "canadianisms de bon aloi" - worthy of enriching "universal French".

However, this openness does not alter the normative hierarchy dominated exclusively by the "French of France". Indeed, the label "bon aloi" is only awarded to diatopisms (lexical):

- which fill a lexical gap in the French language: these are words designating realities that were not previously named in French, because they are exotic, foreign to a Parisian Frenchman; in other words, they are encyclopaedic regionalisms (culinary specialities, institutional vocabulary, etc);

- which present a signifier that facilitates their integration: a more delicate criterion, but one that will favour a form that seems Roman ${ }^{6}$, such as the feminine noun drève "tree-lined avenue", and eliminate the adverb stoemelings "en catimini", whose signifier betrays its Flemish origin;

- which can claim letters of nobility: a regionalism that prolongs a now extinct use of general French is unquestionably "de bon aloi"; this is the case of the preposition endéans "dans le délai de", which appears as early as the Cantilène de Sainte Eulalie (end of the nineteenth century).

"De bon aloi", therefore, but without any normative competition arising from the adoption of regionalism in the French language of reference: lexical particularism only becomes "universal" in the absence of an equivalent legitimate form. One constant of purist discourse is therefore not called into question: the primacy of THE exogenous norm over all endogenous uses. This is a characteristic that runs through the entire history of the French language, associating political, 
${ }^{7}$ For a detailed study of this stigmatisation in the current representations of certain Frenchspeaking Swiss, cf. Prikhodkine (2011). This author's observations are similar to those made for Belgium in particular, except that they focus on the only Germanisms that are clearly identifiable (particularly in terms of their phonetic form). For greater relevance, the analysis should also include

"unconscious" Germanisms, not identified as such by the speakers (such as "trade promotion" action, "parliamentary group" fraction, etc.).

\footnotetext{
${ }^{8}$ Provincialisms - particularly Gasconisms - have been vilified since the XVIth century, a break with the tolerance and even interest shown by the Pleiade in the previous century. In addition to the condemnations of Boileau, Vaugelas et al., we can mention the Gascony article in the Dictionnaire de l'Académie which, presented in a relatively "neutral" manner in the first edition of 1694 ("subs. masc. Façon de parler introduite par les Gascons, qui vient de Gascogne" $e^{\prime \prime}$, is clearly stigmatised in the third edition (1740), where it is written: "GASCONISME s. m. Construction vicieuse dans la langue, \& qui est tirée de la manière de parler des Gascons. Cela n'est pas françois, c'est un gasconisme"

('Gasconisme : flawed construction in the language \& which is taken from the Gascons' manner of speaking. This is not Francois, it is Gasconism').
}

economic, social and cultural centralisation with linguistic centralisation of which Paris is the mythical embodiment.

\section{Stigmatisation of the interference of "local French" with languages in contact with each other}

One might wonder what other criticisms are levelled at the "French from here", apart from their distance from the "French of Paris". A distance which, in itself, is not in any way demeaning. We do not lack testimonies from French visitors to certain colonies or distant regions, who point out that the natives speak excellent French, sometimes even better, they say, than that spoken in Paris.

But alongside this praise, there are many condemnations of the "galimatias" of this or that population indiscriminately mixing French with languages in contact. This stigmatisation has been present in Belgium since Poyart, whose title is "Flandricism and Walloonism": Flemish and Walloon denature the purity of French, bastardise it.

The stigmatisation of languages in contact is selective; this selection is based on the origin of the language concerned. We know the repercussions of the talk given at the Cercle catholique de Québec in 1880 by Jules-Paul Tardivel (1851-1905), entitled: "Anglicism is the enemy". In Europe, it would be more like, "Germanism is the enemy". The stigmatised influence yesterday and today - of Germanic languages in contact with French is that of Alsatian in Alsace, Flemish in Belgium, Lëtzebuergesch in the Grand Duchy of Luxembourg, Swiss German (Schwyzerdütsch) in Switzerland7. These negative representations are still relevant in these countries and regions.

However, the situation is somewhat different for the Romance regional languages. In Acadia and Quebec, the borrowings associated with the regional languages of the colonists (Poitevin, Saintongeais and others) have been better accepted than Anglicisms and can be seen positively because they attest to the link with France. In Europe, the situation is more complex. In the second half of the 19th century (cf. Desgrouais' Gasconismes corrigés, published in 1766 and republished many times ${ }^{8}$ ), the purist tradition did not fail to condemn the borrowings or tracing of patois, which were considered as survivals of obscurantism in the face of the 
Enlightenment. In France, then in Switzerland, primary school (compulsory and free) simultaneously promoted the teaching of French and the eradication of regional languages; hence the gradual disappearance of these "patois" between the end of the 19th and the beginning of the 20th centuries. This disappearance will make the stigmatisation less and less virulent, since it is deprived of purpose, and even generate a current of sympathy for these reminiscences of a lost paradise, which one of my colleagues nicely calls "les fonds de terroir".

In Belgium, where compulsory primary education only came into force in the 1920s, the Romance regional languages lasted much longer than in Switzerland or France, since they still survive today. Vilified by purists since Poyart, these endangered languages are beginning to arouse a current of sympathy which, although it does not have the means to ensure their survival, increasingly associates their heritage with an important component of the identity of the Walloons - and more broadly of French-speaking Belgians. This development therefore weighs more heavily than in France or Switzerland (or Quebec or Acadia) on judgements of normativity and leads to a reappraisal of endogenous norms.

\section{The scientific and social legitimisation of the French from here}

\section{The methodological autonomisation of regional French}

Recognition of the geographical variation of French has long remained marginalized, both in studies dealing with "reference" French (which is explicable) and in contributions more oriented towards local or regional linguistic realities (THIBAULT, 2008).

General lexicographical works make little mention of regionalisms before the Supplement (1877) to Littrés Dictionnaire

${ }^{9}$ The use of the terms patois and dialect varies from one author to another, sometimes considerably. In this paper they refer to regional languages, as in the most widespread tradition in Europe, and not to (social) varieties of languages as in the Anglo-Saxon tradition. de la langue française. After this Supplement, diatopic variation remained little present in "reference" dictionaries until the second half of the 20th century. In the homogenising conception of languages which has long prevailed, interference between THE French language and a particular regional language ("dialect", "patois") could only be marginal, both from the point of view of linguistic description and from that of the perception of the speakers. 
${ }^{10}$ Somewhat systematic studies of regional varieties of French show that innovations and (archaic) survivals are more numerous than borrowings from patois.

\footnotetext{
${ }^{11}$ The same concept underlies the methodological explanation given by Paul Imbs concerning regional terms, which "were accepted insofar as it was certain that they were not only dialectical, but were in use in a given region among inhabitants who were ignorant of the dialect and who used them spontaneously without having the idea of distinguishing themselves from the common language [...]" (Preface to the Trésor de la langue française).
}

The decline of the regional languages of Gallo-Romania, which began at the end of the 19th century, as mentioned above, will considerably change this situation. The European dialectological tradition, which also dates back to the 19th century, was gradually to be deprived of its object of study (as an observable reality in the field), with a two-fold consequence:

- We recognise the existence of "regional French" which, until then, only certain precursors had clearly identified (Pierrehumbert in Switzerland, etc.); "regional French" which cannot be confused either with the French of reference or with "patois", and which impose themselves as autonomous objects of study, no longer as unstable hybrids, irreducible to any systematic observation;

- However, at least initially, there will be a transposition to the study of regional French of concepts and methods that are in line with research on regional languages (FRANCARD, 1991; CHAMBON, 1997). This transposition, which is particularly true for France, is facilitated by the (erroneous ${ }^{10}$ ) view that regional French is a sort of "natural" extension of endogenous regional languages: this is expressed in the well-known formula: regional French "is what remains of the patois when it has disappeared". (TUAILLON, 1974, p. 576) ${ }^{11}$

It was not until the end of the 20th century that this approach, inherited from classical dialectology, gave way to a methodology that treated the French here, no longer as survivors of a patoistic substratum, but as varieties with their own dynamics. This methodology is the differential approach, based on a "corpus of exclusion" (the French of reference), understood as:

the French variety constituted by all the usages listed in the major dictionaries of French (Trésor de la langue française, Le Grand Robert de la langue française, Le Grand Larousse de la langue française, le Dictionnaire de l'Académie française) and in the usual dictionaries (le Lexis, Le Petit Robert, le Dictionnaire Hachette encyclopédique, le Petit Larousse, etc.) ; authoritative grammars, such as Le bon usage, are also part of the corpus of reference French. (POIRIER, 2000, p. 150-151) 
The description of a particular geographical variety, of a particular "français d'ici", is made by taking into account the significant differences that characterize the variety described in relation to the reference French. This focus on specific features - preferred for pragmatic reasons to a global description of the variety under study - has not only enabled the study of the geographical variation of French to be emancipated from that of regional languages (dialects), but also, when disseminating its work, has enabled a scientific discourse to emerge which recognises the autonomy of regional French in relation to regional languages.

This methodology will mainly be developed and illustrated by a number of major lexicographical projects which will lead to high-quality descriptions of geographical varieties of French (THIBAULT, 1997; POIRIER, 1998; RÉZEAU, 2001). It owes much to researchers from North America. This does not seem to me to be a (fortunate) coincidence, inasmuch as the autonomy of Quebec French from the regional languages of France - which some settlers conveyed - was obvious to the descriptors, long before this perception became a reality for European linguists.

\subsection{The lexicographical guarantee}

Differential lexicography will make accessible to a wide public the result of the epistemological and methodological shift that has just been mentioned, i.e. the perception of varieties of French as an autonomous object of study both in relation to reference French and in relation to regional languages. This evolution will be confirmed and amplified thanks to the usual dictionaries of French which will include - and therefore support - forms from various "peripheral" French-speaking communities.

This movement began to take shape in the 1970s, particularly in Belgium with Maurice Piron, who pleaded for a "general inventory of the 'customs' of the Frenchspeaking world" (PIRON, 1975), a project taken up in the 1980s by Bernard Quemada. It was a time when the idea of a "universal French" was gaining ground, to which the Frenchspeaking communities would contribute through their own particularities... and with good reason. Hence the gradual 
opening of the usual dictionaries to the "French-speaking world outside France", as these quotations from the Petit Robert and the illustrated Petit Larousse attest:

Il est paradoxal que des dictionnaires consacrés au français moderne négligent totalement la réalité langagière de communautés francophones importantes et influentes (Petit Robert, "Présentation du dictionnaire", 1977, p. xix, under the signature of Alain Rey) (It is paradoxical that dictionaries devoted to modern French totally neglect the linguistic reality of important and influential French-speaking communities) . Une part très importante a été faite par ailleurs à la francophonie hors de France (Belgique, Suisse, pays d'Afrique, Québec, Louisiane) ainsi qu'aux vocabulaires français régionaux (Petit Larousse illustré, "Aux lecteurs", 1989, p. 6). (A very important part was also given to the French-speaking world outside France (Belgium, Switzerland, African countries, Quebec, Louisiana) as well as to regional French vocabularies).

Of course, this openness to geographical variation is well marked out, as the editors of the Petit Robert make clear:

[1]a description du français hors de France dépasse de loin les objectifs et les possibilités d'un ouvrage réalisé à Paris. (Petit Robert, "Préface", 1977, p. XIX, under the signature of Alain Rey). (The description of French outside France goes far beyond the objectives and possibilities of a book written in Paris).

Cependant, l'objectif du Nouveau Petit Robert n'a pas varié par rapport à celui du Petit Robert qu'il continue : c'est la description d'un français général, d'un français commun à l'ensemble de la francophonie, coloré par des usages particuliers, et seulement lorsque ces usages présentent un intérêt pour tout le monde. (Nouveau Petit Robert, "Préface", 1993, p. XIII, under the signature of Josette Rey-Debove and Alain Rey). (However, the objective of the Nouveau Petit Robert has not changed from that of the Petit Robert which it continues: it is the description of a general French, a French common to the whole of the French-speaking world, colored by particular usages, and only when these usages are of interest to everyone).

The reception of "foreign" forms within the French language of reference is therefore a matter of "chosen" immigration, which does not upset the hierarchy of norms. The fact remains that the conjunction between, on the one hand, the 
${ }^{12}$ For an analysis of diatopic marking in the Petit Robert, see Brochard (2005). lexicographical work of specialists on the varieties of French and, on the other hand, the opening up to diatopic variation of the usual dictionaries has accelerated the legitimisation of "local French" and, at the same time, the questioning of the exclusivity of France - and particularly of Paris - in terms of linguistic legitimacy.

This legitimization of endogenous forms, apart from the markers already mentioned in relation to the usual dictionaries, remains limited:

- This evolution essentially concerns the lexicon, especially in its creations (innovations) or its survivals (archaisms); for pronunciation, the situation is more confused; as for morphology or morphosyntax, it is hardly taken into account;

- Endogenous norms are recognised within a restricted linguistic market (that of the linguistic community concerned): such Belgicism, such Acadianism may find a place in the Petit Robert, but always accompanied by the reg(ional) mark ${ }^{12}$;

- The recognition of endogenous norms is of varying importance depending on the community: the Frenchspeaking communities in the "first circle" (Belgium, Canada, Switzerland) are much better represented in the usual dictionaries than communities in the South, for example.

In other words, if there is recognition of endogenous norms, there is not yet a reversal of the hierarchy that would put these norms on the same level as the exogenous "Parisian" norm. The recognition of a linguistic legitimacy for "local French" is therefore ambiguous. This is perceptible both in metalinguistic discourse (which has just been mentioned in the prefaces to the reference dictionaries) and in epilinguistic productions, as shown by the reception, in French-speaking communities outside France, of dictionaries - reference dictionaries (FRANCARD, 2011), or differential dictionaries which are increasingly welcoming diatopisms. 


\section{The construction of judgements of normativity}

Research on diatopic variation has focused not only on language practices, but also on the attitudes and representations associated with this type of variation. In particular, they have studied the discursive manifestations of various forms of linguistic discrimination (linguistic insecurity, diglossal conflicts, etc.) in the people who experience them.

These people have been assimilated to "peripheral Francophone speakers", an association which is both:

- exact: there is indeed discrimination against these speakers from the point of view of linguistic legitimacy, because of their geographical roots;

- but approximate: not all peripheral French speakers suffer the same discrimination, not all have the same type of legitimacy deficit; but, above all, some of them play an active role in the discrimination process.

These agents that contribute to the processes of discrimination and whose action ranges from the micro- to the macro-sociolinguistic can be:

\footnotetext{
${ }^{13}$ The term

glottopolitics refers to "the various approaches that a society takes to language, whether or not it is aware of them: language, for example, when society legislates on the reciprocal status of French and minority languages; speech, when it represses a particular use in a particular language; discourse, when schools produce a particular type of text for examination..." (Preface to the Trésor de la langue française, 2005): "Glottopolitics is necessary to encompass all the facts of language in which the action of society takes the form of politics" (GUESPIN, MARCELLESI, 1986, p. 5).
}

- glotto-political instances ${ }^{13}$ : the educational institution, the media, certain cultural organisations, etc.

- but also social actors: teachers, parents, journalists, language columnists, readers, etc.

The observation of parallel evolutions in the metalinguistic productions of specialists and in the epilinguistic discourse of speakers raises the question of the respective weight of the actors (institutional and private) in the field of the legitimization of 'local French', as in other fields where power relations mediated by the language are at stake. This questioning is common practice in critical sociolinguistic works (Monica Heller, Alexandre Duchêne and, for Acadia, Annette Boudreau and Laurence Arrighi in particular). It seems to me that it is still to be exploited in the study of the normative legitimization of diatopic uses, with reference to geographical bases. 
${ }^{14}$ It would be

interesting to ascertain whether this lack of explicit institutional discourse on the eradication of regional languages and the need to adopt a French 'de France' is found in other peripheral francophone communities and, if so, what the explanation might be. In the case of the Belgian Romanists referred to above, it may be that their discretion on these subjects in the public space was due to the conflict of loyalty they felt between safeguarding the uses they practised on a daily basis (including regional languages) and promoting the 'French of France' that they were supposed to teach.
The analysis of the role of various actors in the processes of linguistic legitimation might seem easy: their identification does not pose a problem and it is sufficient to collect their productions. My experience leads me to moderate this optimism, for the following reasons:

(i) In trying to gain a better understanding of the process of linguistic denial which, at the turn of the 1920s, targeted both the regional languages and French as practised in Belgium, I have found that the designated institutional players (the school institution in particular) do not seem to have left any written record of their actions. There is no law, no official teaching instructions: so far, there is nothing to be found in the books or in the pen.

(ii) When I turned to personalities who I knew had played a decisive role in the evolution of normative judgements in French-speaking Belgium - in particular university professors from the departments of French and Romance Studies - I collected personal positions, such as those that can be expressed in the introduction to a book or in an article; but, again, nothing about the "glotto-linguistic" action actually carried out by these actors ${ }^{14}$.

(iii) Another observation is that, in mechanisms of linguistic discrimination, the distribution of the roles of the actors is not always clear-cut. Some actors are far from having a clear awareness of their role: the role of guarantor of linguistic hegemony or, conversely, the role of "victim" of this hegemony is not always clear to the consciousness of those concerned.

(iv) A final observation, of a methodological nature: the analysis of the role of those involved in the construction of judgements of normativity cannot be limited to the corpus of discursive manifestations. It also includes an evaluation of the influence of these actors, with questions of a quantitative nature: which school, which school population is affected by a given piece of legislation with a linguistic scope? How many readers read the language columns in a given newspaper? What is the general public's reception of a given standard dictionary? 
Which networks (including social networks) disseminate normative judgements?

There are also questions of a more qualitative nature: how are roles distributed in the school hierarchy? Who ultimately influences the application of educational guidelines? Who are the influential intelligentsias in the cultural sphere? Which emblematic personalities mediate "language models"? What weight is given to the creation of a Francophone educational institution, such as a Francophone university in Moncton, and, within it, to the development of sociolinguistics?

Questions of this nature have already been asked, including in our field of research, but they would benefit from being linked to the other questions we are dealing with, particularly in the discursive sphere. 


\section{Addendum}

${ }^{15}$ Note 1 provides the reference to the full article. This contribution first presents morphological features grouped according to grammatical classes (determiners, prepositions, conjunctions, adverbs, verbs); then it highlights some syntactic constructions related to the order of words, then to the specific use of tenses such as the imperfect or modes such as the infinitive. Some particularities are commented on from the point of view of their origin and their possible diffusion in other French-speaking areas. Finally, a brief reflection is offered on the quantitative imbalance between grammatical variation, which is not very apparent in the usage of French-speaking Walloons and Brussels speakers, and the lexical variation which is much more striking.

${ }^{16}$ Under certain generic entries in the Dictionnaire des belgicismes (FRANCARD, Michel in collaboration with Geneviève GERON, Régine WILMET and Aude WIRTH, Brussels, De Boeck, 20152 [20101]) such as DETERMINANT, GENRE, NUMBER, you will find a list of grammatical belgicisms.
The present contribution focuses on lexical features, leaving other areas of linguistic variation, including grammar (in the broadest sense), in the shade. While a few studies address this point of view, we do not have an in-depth description of the morphological and syntactic specificities of Belgian French.

An overall presentation of these characteristics - which remains incomplete, however - has been written by the author of these lines for the journal Information grammaticale ${ }^{15}$. The illustrations below are taken from the review to give a brief overview of the grammatical variation in Belgian French.

\section{Some morphological observations ${ }^{16}$}

\section{Determinants}

In a number of usages, the determinant is absent in the usage of French-speaking Belgians, whereas it is required in reference French: de commun accord "d'un commun accord", 'by mutual agreement'; aller à selle "aller à la selle", 'defecate'; sur base de "sur la base de", 'on the basis of', etc. Conversely, there are cases where the determinant is present in Belgian French, whereas it is absent in reference French: pour $d u$ bon "pour de bon", 'for good'; faire du cas de qqn/qqch., "faire cas de qqn/qqch.", 'make an example of sb/sth'; attraper un froid "attraper froid", 'to catch a cold'.

\section{Prepositions}

A series of prepositional idioms distinguish themselves from the French of reference. One can quote assez bien de "pas mal de", 'quite a lot of' (il y avait assez bien de monde à la cérémonie, 'there were quite a few people at the ceremony'); dans le chef de "s'agissant de, dans le cas de", 'in the case of' (dans le chef d'une personnalité publique, c'est inacceptable, 'in the case of a public figure, this is unacceptable'); endéans "dans un délai de" (à payer endéans la quinzaine, 'to be paid within a fortnight'), etc.

In addition, many prepositions in Belgium have unusual constructions in the French of reference. Amongst many others, we can mention mettre à place "en",'set up'; la confiture aux fraises 
"de", 'strawberry jam'; se mesurer contre qqn "à/avec", 'to measure oneself against sb; priorité de droite " $a$ ", 'priority to the right', etc.

\section{Conjunctions}

In Belgian French, there are a few specific conjunctive locutions of a formal point, such as si en cas "si par hasard" (si en cas tu changes d'avis, téléphone-moi, if by chance you change your mind, phone me'); encore bien que "heureusement que", "fortunately " (encore bien que j'ai retrouvé mes clés, 'fortunately I have found my keys'); jusqu'à tant que "jusqu'à ce que", 'until' (je resterai jusqu'à tant que qu'il soit guéri, 'I will stay until he is cured'); sur le temps que "pendant que", 'while' (sur le temps que je serai en ville, prépare à manger, 'durant the time I'm in town, prepare diner), etc.

Characteristic are also the uses of phrases marking sufficiency, excess or insufficiency, associated with the adverbs assez, suffisamment, trop, trop peu (+ adjective, adverb or noun) and which are constructed not only with the preposition pour, as in reference French, but also with the conjunction que (+ infinitive): tu es assez grand que pour te débrouiller seule, 'you are big enough to manage on your own'; il gagne suffisamment d'argent que pour vivre sans se priver, 'he earns enough money to live without depriving himself'; il est trop lent que pour pouvoir rivaliser avec les meilleurs, 'he is too slow to be able to compete with the best'; je suis trop peu présent que pour pouvoir vous assister, 'I am not present enough to be able to assist you'.

\section{Adverbs}

Belgian French has a few adverbial phrases of its own: comme pour rien or comme pour rire "comme rien ; facilement", "easily" (cette machine broie les souches comme pour rien, comme pour rire , 'this machine grinds up the stumps like nothing, as if for laughing'); au plus souvent "le plus souvent" (je me promène chaque dimanche, au plus souvent après le dîner , '(I go for a walk every Sunday, usually after dinner'); par après "par la suite" (par après, elle n'a plus donné signe de vie, 'afterwards, she gave no further sign of life'); assez bien "assez, passablement" (in a quantitative point of view), "enough" (il y avait assez bien de monde sur la place, "there were quite a few people in the square"). 
Other specificities relate to the functioning of the adverb. We can mention the use of si pour aussi, 'also', in compositions : si longtemps que "jusqu'à ce que", 'until, as long as' (elle veut rester si longtemps que sa mère est malade, "she wants to stay as long as her mother is ill"); si vite que "aussitôt que", "as soon as" (si vite qu'il ser arrivé, préviens-moi, "as soon as he arrives, let me know"). Or note the rich semantics of the locution encore bien: "peut-être", 'maybe' (+ conditional) (tu aurais encore bien raison, 'you might be right'); "de plus, par-dessus le marché", 'moreover, on top of that' (c'étaient des locaux crasseux, sans chauffage encore bien, 'they were filthy premises, moreover without heating); "parfois", 'sometimes' (il revient encore bien chez ses parents le weekend, 'he still goes back to his parents on the weekend); "assez", 'quite' (j'aime encore bien aller au thêâtre, 'I quite like going to the theatre').

\section{Verbs}

Verbs give rise to many observations. Some are related to verbs that behave like pronouns, whereas they are transitive or intransitive in the French of reference: s'accaparer (qqn/ qqch) or s'accaparer de (qqn/qqch) "accaparer (qqn/qqch)", 'to monopolise (sb or sth.)'; conversely, intransitive usages can be found in Belgian French, where the French of reference favours pronominal constructions: baigner "se baigner", 'to bathe' (je vais baigner, 'I am going to bathe'); coucher "se coucher", 'to lie down; to go to bed' (il est temps d'aller coucher, 'it is time to go to bed').

A series of verbs present absolute constructions that the French of reference does not know. Such is the case of accompagner "se joindre (à qqn)", 'to accompany (to sb)' (nous allons au thêatre ce soir; tu accompagnes ?, 'we are going to the theatre tonight; will you join us?'); aimer autant, "accepter", 'to accept' (tu veux une tasse de café ? J'aime autant, 'do you want a cup of coffee? I like it so much'). We can also mention absolute uses of verbs whose transitive construction is a "Belgian" specificity: attendre, "être enceinte", 'to be pregnant' (elle attendait déjà quand ils se sont mariés, 'she was already pregnant when they got married'); goûter, "plaire par le gout", 'to please by taste' (le boudin, ça goûte mieux quand c'est chaud, 'blood sausage tastes better when it is hot'). 
One of the most emblematic peculiarities of Belgian French is the use of savoir for pouvoir. More precisely, the use of savoir - instead of pouvoir - with an inanimate subject: mon ordinateur ne sait plus démarrer, 'my computer can no longer start'; la fenêtre ne sait plus se fermer, 'the window can no longer close'; ma voiture sait faire du 200 à l'heure, 'my car can go up to 200 kilometers an hour'. Other expressions that present savoir with an animated subject (usually in negative contexts) are also common in French-speaking Belgium, but this use goes well beyond the North of France.

\section{Some syntactic observations}

Word order

A few specific observations concerning the order of words in Belgian French deserve to be made. One of the most interesting concerns the adverb assez, which is postponed after an adjective, adverb or noun to express a sufficient degree of quantity or quality: pas besoin de l'aider, il est malin assez, 'no need to help him, he is clever enough'; impossible de le suivre, je ne cours pas vite assez, 'impossible to follow him, I don't run fast enough'.

Another characteristic to be noted is the anteposition of certain epithet adjectives generally postponed to the noun in the reference French. The inventory of these adjectives is relatively limited: there are antinomic pairs (propre/sale, 'clean/ dirty', blanc/noir, 'white/black'), as well as adjectives such as fin, 'fine', laid, 'ugly' or court, 'short', all taken in their original meaning. Hence des courtes manches, "des manches courtes", 'short sleeves'; une laide ville, "une ville laide", 'an ugly city'; une propre serviette, "une serviette propre", 'a clean towel' (= that has been washed)'; du noir café, "du café noir", 'black coffee'.

\section{Ludic Imperfect}

Several studies mention, for French-speaking Belgium, a value of the imperfect called ludic (or preludic). This is the imperfect used by children who divide up the roles before starting a game: on disait que j'étais le papa et toi la maman ('let's say that I was the daddy and you were the mommy'); toi tu étais le gendarme et moi le voleur, 'you were the gendarme and I was the thief'. If general French prefers the conditional here 
to express the quest for approval of the conventions that will govern the ludic activity, the Belgian use of the imperfect invites us to take these provisions for granted, for the entire duration of the game.

\section{Coordinated infinitive to a conjugated verb}

This syntactic feature is characteristic of Walloon syntax and is passed on to regional French. It is the coordination of an infinitive to a conjugated verb, in statements such as il faut que je revienne et recommencer à travailler, "il faut que je revienne et recommence à travailler", 'I must come back and start working again'; au cas où il quitterait ses parents et se marier, "au cas où il quitterait ses parents et se marierait", 'in case he leaves his parents and gets married'; tu apportes ton linge et me laisser le laver, "tu apportes ton linge et me laisses le laver", 'you will bring your laundry and let me wash it'. The infinitive appears regardless of the mode, tense or person markings of the conjugated verb to which it is related.

\section{Conclusion}

The above observations (some of which are undoubtedly specific to the Belgian situation) should not discourage us from conducting this research on the "levers of power" that regulate the normative hierarchy between geographical varieties of French. This is in order to better understand the mechanisms implemented, their manifestations, their effects, but also to better circumscribe the hegemonic nature of certain policies and to envisage social operations that would not have the same effects.

This research on "levers of power" seems to me to be at the heart of our profession. A linguist, whose work regularly confronts the balance of power linked to the use of languages, cannot remain indifferent to the social cost of linguistic discrimination. Especially if this linguist is convinced, moreover, that a community can emancipate itself from linguistic hegemony, however heavy it may be. And that a real appropriation of French by the communities that make up the French-speaking world is essential for them to "live well in French". 
I owe this conviction in large part to my discovery, several decades ago, of the Acadian francophonie, and then to its recent evolution. My speech today is a testimony to my sincere gratitude for the people who made this discovery possible.

\section{REFERENCES}

ASSOCIATION QUÉBÉCOISE DES PROFESSEURS DE FRANÇAIS ET ÉMILE BESSETTE. Le congrès du dixième anniversaire ; les résolutions de l'assemblée générale. Québec français, n. 28, p. 10-12, 1977.

AYRES-BENNETT, Wendy. Les ailes du temps et la plume du "remarqueur" : la tradition puriste au XIXe siècle. Romantisme, n. 86, v. 24, p. 33-46, 1994.

BARTHÉLEMY, Prosper. L'omnibus du langage. Dijon: Victor Lagier, 1839.

BROCHARD, Marie-José. La représentation des variations diatopiques dufrançais dans le Petit Robert : enjeux et contraintes. In: GLEßGEN, Martin-D ; THIBAULT, André (org.). La lexicographie différentielle du français et le Dictionnaire des régionalismes de France. Strasbourg: Presses Universitaires de Strasbourg, 2005. p. 281-288.

CHAMBON, Jean-Pierre. L'étude lexicographique des variétés géographiques du français en France: éléments pour un bilan méthodologique (1983-1993). Lalies, n. 17, p. 7-31, 1997.

DESGROUAIS, Jean. Les Gasconismes corrigés. Ouvrage utile à toutes les Personnes qui veulent parler et écrire correctement, et principalement aux jeunes gens, dont l'éducation n'est point encore formée (1re édition). Toulouse: J.-J. Robert, 1766.

DOPPAGNE, Albert. Belgicismes de bon aloi. Bruxelles: Office du bon langage, Fondation Charles Plisnier, 1979. 
FRANCARD, Michel. Français régional et francisation d'un dialecte : de la déviance à la variation ». In: XVIIIe congrès international de linguistique et philologie romanes (Trèves, 19-24 mai 1986). Annales [...], tome III. Tübingen: Max Nimeyer Verlag, 1991. p. 370-382.

. Les jeunes francophones et leur langue: de l'Acadie du Nouveau-Brunswick à la Wallonie. Revue de l'Université de Moncton, vol. 27, n. 1, p. 147-160, 1994.

Attitudes et représentations linguistiques en contexte minoritaire: le Québec et l'Acadie. In: VALDMAN, Albert; AUGER, Julie Auger; PISTON-HATLEN, Deborah (dir.). Le français en Amérique du Nord : état présent. Québec: Presses de l’Université Laval, 2005. p. 371-388.

L'intégration des régionalismes dans les dictionnaires de référence du français. Le cas des belgicismes ». In: SINDACO, Sarah (dir.), Jean-Marie Klinkenberg, un homme d'(inter)action. Fernelmont: E.M.E. éditions, 2011. p. 13-25.

Le français d'ici est-il du français ? Jugements de normativité dans les communautés francophones périphériques européennes. In: ARRIGHI, Laurence; GAUVIN, Karine (org.). Regards croisés sur les français d'ici. Québec: Presses de l’Université Laval, 2018. p. 251-268.

Les belgicismes grammaticaux : une denrée rare dans la terre des grammairiens ?. In: AVANZI, Mathieu; THIBAULT Thibault (org.). L'Information grammaticale (numéro thématique : «La variation régionale en grammaire »), n. 166, juin 2020. p. $42-51$.

; LAMBERT, Joëlle; MASUY, Françoise. L'insécurité linguistique dans la Communauté française de Belgique. Bruxelles: Service de la langue française, 1993.

; GERON, Geneviève, WILMET, Régine. L'insécurité linguistique dans les communautés francophones périphériques. Louvain-la-Neuve : Cahiers de l'Institut de linguistique de Louvain, vol. 19, n. 3-4, vol. 20, n. 1-2, 1994. 
GUESPIN, Louis; MACELLESI, Jean-Baptiste. Pour la glottopolitique. Langages, n. 83, p. 5-34, 1986.

HANSE, Joseph; DOPPAGNE, Albert; BOURGEOIS-GIELEN, Hélène. Chasse aux belgicismes. Bruxelles: Office du bon langage, Fondation Charles Plisnier, 1971.

. Nouvelle chasse aux belgicismes. Bruxelles: Office du bon langage, Fondation Charles Plisnier, 1974.

IMBS, Paul. Préface. In: IMBS, Paul; depois QUEMADA, Bernard. Trésor de la langue française. Dictionnaire de la langue du XIXe et du XXe siècle (1789-1960). Paris: Éditions du Centre national de la recherche scientifique, depois Gallimard. 19711994.

LITTRÉ, Émile. Dictionnaire de la langue française : supplément. Paris: Hachette, 1877.

PETIT LAROUSSE ILLUSTRÉ 1989 (1988), « Aux lecteurs », Paris, Larousse, p. 5-8.

PIRON, Maurice. Pour un inventaire général des "usances" de la francophonie. Bulletin de l'Académie royale de langue et de littérature françaises, vol. 53, fasc. 2, 1975. p. 111-122.

POIRIER, Claude (org.). Dictionnaire historique du français québécois. Sainte-Foy: Presses de l'Université Laval, 1998.

. Le français de référence et la lexicographie différentielle au Québec. In: FRANCARD, Michel (org.). Le français de référence : constructions et appropriations d'un concept. Louvainla-Neuve: Cahiers de l'Institut de linguistique de Louvain, vol. 26, n. 1-4, p. 139-155. 2000

POYART, Antoine-Fidèle. Flandricismes, wallonismes et expressions impropres dans le langage français. Bruxelles: J. Tarte, 1806

PRIKHODKINE, Alexei. Dynamique normative du français en usage en Suisse romande. Enquête sociolinguistique dans les cantons de Vaud, Genève et Fribourg. Paris: L'Harmattan, 2011 
RÉZEAU, Pierre (org.). Dictionnaire des régionalismes de France. Louvain-la-Neuve: De Boeck-Duculot, 2001

REY, Alain. Présentation du dictionnaire. In : Le Petit Robert : dictionnaire alphabétique et analogique de la langue française. Paris: Société du Nouveau Littré, 1977, p. ix-xix.

THIBAULT, André (sous la dir. de Pierre Knecht). Dictionnaire suisse romand: particularités lexicales du français contemporain. Une contribution au Trésor des vocabulaires francophones. Carouge-Genève: Zoé, 2004 [1997]

. Lexicographie et variation diatopique : le cas du français. In: COLOMBO, Maria; BARSI, Monica (org.). Lexicographie et lexicologie historiques du français : bilan et perspectives. Monza: Polimetrica International Scientific Publisher, 2008. p. 69-91.

TUAILLON, Georges. Compte rendu de l'ALIFO [Atlas linguistique et ethnographique de l'Île-de-France et de l'Orléanais]. Revue de linguistique romane, n. 38, p. 575-576, 1974. 


\section{Resumo}

Francês daqui, é francês? a construção de juízos de normatividade em comunidades francófonas periféricas da Europa

O presente artigo trata da variação diatópica do francês e de sua relação com o discurso normativo, mais especificamente o francês praticado na Bélgica, exemplificado neste trabalho nos campos do léxico e da sintaxe. Descreve-se o discurso purista do século passado, que está evoluindo rumo a uma modificação da hierarquia normativa, uma emancipação da hegemonia linguística, tanto no mundo científico quanto nas representações dos falantes. Este artigo também leva a um questionamento da identidade dos atores responsáveis pela construção de juízos de normatividade.

Palavras-chave: Francês belga. Norma endógena. Discurso normativo. Sintaxe. Atores glotopolíticas.

Michel Francard é Doutor em filosofia e letras pela Universidade Católica de Louvain (UCL); Professor titular da Universidade Católica de Louvain (UCL). Autor de inúmeras contribuições científicas sobre as variedades do francês na Francofonia e sobre as línguas minoritárias. Fundador do centro de pesquisas Valibel (UCL). Desenvolve pesquisas na área de variedades linguísticas. 